\title{
Public relations and communication management in Europe: challenges and opportunities
}

Betteke van Ruler* \& Dejan Verčič**

\begin{abstract}
In most European countries, public relations is a flourishing industry, sometimes with a history of a least a century, and all over Europe young people like to become educated in the field. Nevertheless, little is known about crucial aspects of public relations in Europe and so far there is even lesser debate and knowledge exchange on these aspects. The research projects we have conducted so far show that public relations is a multi-dimensional concept. These different dimensions show that public relations is not just a professional function of managers and technicians. The question we want to raise in this article is what typifies European public relations in practice, education and research and what could be a unifying concept to develop practice, education and research.
\end{abstract}

Keywords: communication management, professionalism, public relations, Europe

\section{Introduction}

In most European countries, public relations is, although not always named as such, a well-known phenomenon. It is a flourishing industry with a history of at least one century, and all over Europe young people like to become educated in this field. Nevertheless, little is known about crucial aspects of public relations in Europe and so far there is even lesser debate and knowledge exchange on these aspects. Therefore,

\footnotetext{
* Betteke van Ruler is Professor of Communication and Organization and Chair of the Department of Communication Sciences of the University of Amsterdam. She is also President-Elect of the European Public Relations Research and Education Association (Euprera).

** Dejan Verčič is a founding partner in Pristop Communications consultancy in Ljubljana, Slovenia and assistant professor in the Department of Communication Science at the Faculty of Social Sciences, University of Ljubljana in Slovenia. E-mail: Dejan.Vercic@Pristop.si. Website: http://www.vercic.pristop.si.
} 
the European Association for Public Relations Education and Research (Euprera) initiated the European Public Relations Body of Knowledge project (EBOK) in 1998. The purpose of the EBOK project is to codify the existing body of public relations literature of European origin and to enable its fuller use and recognition, which are at present restricted by linguistic, cultural and administrative barriers (Verčič, 2000). In order to be able to build a good bibliography, the first question that needed to be answered, was whether there is anything specific in European Public Relations, and if so, what its specific content is and what its parameters are. That is why a working group started a Delphi study to discuss current topics in public relations with public relations experts in as many countries as possible. Finally participants from 29 countries could be included in this study (Ruler et al., 2001). At the $9^{\text {th }}$ International Public Relations Research Symposium, held in Bled, Slovenia, July, 2002, the outcomes had been discussed on the basis of the so called Bled Manifesto on public relations, which was in turn based on the Delphi study. In 2004 a follow up study had been released via Public Relations and Communication Management in Europe, a nation-by-nation introduction of theory and practice (see Ruler \& Verčič, 2004). This paper is a combination of different aspects of these two projects.

\section{On "public" in public relations}

Public relations appears to be named differently across Europe. There are differences between countries, but also between sectors within countries. In many countries, when speaking in one's own language, it is even impossible to talk about public relations in the same meaning as the term has in the USA (especially in the Northern and some of the North Western and central European countries). When the term public relations is used, it is seldom used in the North-American way. What Grunig (1992) means when using "public relations" is what in the United Kingdom is commonly named "public affairs". Moreover, the term public relations (if ever used) is more and more being replaced by terms like communication management, corporate communication or integrated communication. Many European public relations associations renamed themselves into some kind of "communication" associations (although some of these still define themselves as public relations associations in English). This has, so far, happened in Denmark, The Netherlands, Finland, Norway, and Sweden. This has to do with bad connotations, but also with the concept of public relations itself.

Names for "public relations" in Germanic and Slavonic languages mean "relations with the public and in the public" where "public" itself denotes a different phenomenon than it is generally assumed to mean in the public relations discipline in English. Here we take the German term for "public relations" as an example, but similar explanations apply to other Germanic and Slavonic languages (and thus covering much of the Northern, Central and Eastern parts of the European continent). The German term for "public relations" is "Öffentlichkeitsarbeit", which literally means "public work" and is explained as "working in public, with the public and for the public" (Nessman, 
2000). This denomination contradicts the mainstream (U. S.) understanding of public relations as management of relationships between an organization and its publics (see a. o. Bernays, 1986; Cheney \& Dionispoulos, 1987; Hutton, 1999). Yet, it also needs to be recognized that Olasky (1989), inspired by the German sociologist Habermas, proposed an alternative approach to the history of public relations as being differentiated from "private relations" (and thus giving also an alternative meaning of public relations as something different from just "relations with publics").

Ever since these Germanic and Slavonic equivalents of the term public relations had been introduced to these languages, it was obvious to the natives that their terms mean something else than the original (U. S. English), as Nessmann (2000) argued. However, it would be wrong to just stop here with the recognition of this terminological problem as being a matter of language(s) only. "Öffentlichkeit" does not mean "public" as in publics, audiences, etc. - it means first of all "public sphere", and to be more specific "that what is potentially known to and can be debated by all". Öffentlichkeit is an outcome and therefore a quality of public communication in society. By equating "public" with "Öffentlichkeit" "an analytical dimension is lost, namely that an essential aspect of public relations is that it is concerned with issues and values that are considered as publicly relevant, which means relating to the "public sphere". This line of thought is strongly developed in Germany and can be found back in many other European countries (Jensen, 2000; see also Oeckl, 1976). Their reasoning is that public relations is not only about relations with the public, but it also creates a platform for public debate and it creates, consequently, a public sphere itself. As Ronneberger and Rühl (1992) argued, public relations is to be measured by quality and quantity of the public sphere, it co-produces by its own activities (p. 58). Quality and quantity of the public sphere have to do with "öffentliche Meinung" - which is to be translated as 'public opinion'. However, this public opinion is not an aggregation of individual opinions as conceived in public opinion polling (Price, 1992). It is much more meant as a benchmark for public relations as a type of democratic political authority, and seen as the foundation on which democracy is built (Habermas, 1962). It is, therefore, more a quality than a quantity. Here public relations serves the same kind of (democratic) function as journalism does, while they are both contributing to a free flow of information and to the development of the public sphere in size ("How many people are involved?") and in level ("What is the level at which we are discussing public matters?”). For many European scholars public relations produces social reality and therefore, a certain type of society. That is why many European scholars look at public relations from a sociological perspective instead of an economic, psychological or organizational perspective. In this respect the European use of 'public' and 'public relations' can mean something totally different than it normally does in the United States (Ruler \& Verčič, 2003; see also Verčič \& Sriramesh, 2003). This is why it seems important to globalize the discussion on the fundamentals of public relations and start a true dialogue between continents in order to learn from each other. 


\section{On 'relations' and 'communication'}

The previous point has a strong relationship with the second point of this article: the question whether public relations is all about relationships or all about communication, which used to be an issue in the United States recently. As Heath (2000) mentioned in the preface of his Handbook of Public Relations: "The new view of public relations assumes that markets are attracted to and kept by organizations that can create beneficial relationships" (p. 3). He argued that the paradigm of public relations is changing dramatically into the "underpinning assumption that public relations is a relationship-building professional activity that adds value to organizations because it increases the willingness of markets, audiences, and publics to support them rather than to oppose their efforts"(p. 8). For Ledingham and Bruning (2000) public relations IS relationship management. Also Hutton (1999) described the "new paradigm of public relations, aimed at building relationships with publics". In the concluding paragraphs of their article the proposed definition of public relations ("managing strategic relationships") was said to be breaking with "some long-standing ideas that communication is the bedrock of public relations" and that "communication is a necessary but no longer sufficient foundation for public relations; training in social psychology, anthropology, and other social sciences (not to mention new technologies) is necessary, in addition to business, management and perhaps industry-specific training. "

As it will become clear in our next section, we believe that it makes no sense to differentiate between communication and relationships. From our research projects it is obvious that - at least in Europe - even public relations researchers cannot make any clear difference between communication and relationships. What one sees as communication is what another uses the word relationships for. The arguments for selecting 'relationships' were: 'it is managing relationships with public groups', 'it is all about managing relationships by informing, persuading, dialogue, negotiating', but also 'it is to influence the behavior of parts of the important relationships'. These answers alerted us to the fact that relationships can refer to the relations between parties, to the process of relating, and even to the other party itself. It also showed us that relationship building is not necessarily a merely reciprocal / symmetrical concept. Relationships are obviously a broad and complex concept. The arguments in favor of opting for 'communication' can be summarized as: 'Communication is the most important mean of public relations and relationships are the outcome of it'. Here we also encountered two views of this concept. One was: 'it is the management of communication to mix the activities of the advertisement and promotional fields in the best possible way'. This refers to public relations as 'a tool of marketing', which was a view no one wanted to express explicitly, when asked for. The second view is diametrically opposed to the first: 'PR refers to managing communication by direct or indirect relationships, in order to gain the trust of public groups and to monitor their trust and the consequences it has for the organization. At the same time, $P R$ is the management of information about what is going on inside and outside organizations, with 
the goal of anticipating future situations or to solve already established problems in a proper and less harmful way to the organization. This can only be done by establishing communication, i. e. relationships'. This statement comes close to the view that PR is 'communicating about the organization within society', it also refers to 'managing relationships'. However, it was given as an argument for 'managing communication'. Some participants did not want to choose between these possibilities and, judging by the arguments put forward, it was obvious that none of the others considered this to be a natural division. It is therefore highly questionable if a debate - whether public relations is about management of communication or management of relations - is productive at all. A confrontation of communication with behavior is in the light of the major part of the European social-scientific tradition also nonsense - communication itself being a form of (social) behavior and at the same time being the essence of any kind of relation.

A more revealing point of discussion seems to be, however, what is meant by communication. In this light we believe that an interesting differentiation can be made between for example communication as a certain kind of behavior of people (behavior with signs and symbols) and communication as a process through time and space in which meanings develop and that alters public sphere, a cultural approach.

\section{The parameters of the field}

The third issue we want to raise, has, again, a strong relationship with the former issues. In the first round of our discussion we found many statements about the blurring of public relations with other fields, such as integrated communication management, marketing or even the realms of corporate executives. We wondered whether this was because public relations still has to mature or whether this is simply part of its evolutionary process. Two participants did not see any blurring, and for some participants this is purely a question of semantics. Nevertheless, others think that it is a matter of maturation, while a majority sees it as evolutionary, e. g. a broadening of public relations. This has to do with parameters.

One of our questions in the third round of the Delphi project was 'Is public relations only worthwhile when organizations have problems?' The answers were very clear. Public relations is not just problem handling, it is also a preventive instrument. Arguments that were given, referred to the fact that it also advises individuals within the organization on how to handle their relationships, and on how to develop programs for organizations that 'foster good behavior in communications'. Again, the arguments revealed different roles for public relations.

Analyzing the deliberations of the participants, given in the first round on the question of the relationship with (other) management disciplines, we found the following dimensions of the concept of public relations (see Figure 1). 
Figure 1. Dimensions of the concept of public relations

- A professional management function that initiates or maintains relationships between an organization and its publics

- The communication activities by which an organization can create and maintain long-term relationships with its stakeholders

- A management function to gain public trust and social consensus about the goals of the organization

- A philosophy of strategic management not being market oriented but society oriented

- A tool of marketing to gain a favorable basis for relationships with stakeholders

- A promotional activity to clarify certain goals or conduct of an organization / individual

- A promotional activity to gain public support for the corporate body as a whole

- An informational activity to keep the internal and external society informed

Obviously public relations is not just or not only a professional management function, separated from other functions. This shows that the concept of public relations is a complex concept itself, which cannot be seen as a uni-dimensional one.

In order to define the parameters of public relations more precisely we added five questions into the questionnaire of the second round. The answers are shown in figure 2 .

Figure 2. The parameters of public relations

\begin{tabular}{|c|c|c|c|}
\hline & Yes & No & Depends \\
\hline Must internal communication be part of public relations & 28 & 0 & 0 \\
\hline $\begin{array}{l}\text { Should a PR professional have influence upon the strategy of the organization } \\
\text { as a whole }\end{array}$ & 26 & 1 & 1 \\
\hline Should a PR professional have influence upon the behavior of the employees & 20 & 6 & 3 \\
\hline $\begin{array}{l}\text { Should a PR professional be responsible for the content of the messages he } \\
\text { communicates }\end{array}$ & 17 & 7 & 4 \\
\hline Must marketing communication be part of public relations & 13 & 13 & 2 \\
\hline
\end{tabular}

We may conclude that according to the participants, it is impossible to do public relations without influencing the strategy of the organization and without the responsibility for internal communication. Whether the influence on the behavior of all 
employees belongs to public relations or not, is not clear for everyone; the same counts for responsibility for the content of the messages. There is a strong disagreement as to whether or not external communication includes communication with customers.

Because of the fact that the inclusion of marketing communication within public relations separated the participants, we asked them in the third round to comment on three questions on inclusion or exclusion of marketing communication. This question elicited long answers from many participants. For six participants it was very clear that public relations is also aimed at commercial publics. Most of the others refused to commit themselves and stated that "it all depends".

Part of the refusal to commit on the inclusion of marketing communication has to do with the concept of persuasion, which was also included in the comments the participants gave in earlier rounds. We therefore asked in the third round how we should consider persuasion in the case of public relations. The question was: "Public relations is clearly not to be equated with propaganda, although persuasive strategies are used. Could you please give the borderlines between a persuasive effort on the one hand and propaganda on the other hand or do you want to reject any persuasive effort as part of public relations?”

Figure 3. The concept of persuasion

\begin{tabular}{|c|c|c|c|}
\hline $\begin{array}{c}\text { No persuasion } \\
\text { allowed }\end{array}$ & $\begin{array}{c}\text { As little persuasion } \\
\text { as possible }\end{array}$ & All persuasion is ok & $\begin{array}{c}\text { Persuasion allowed } \\
\text { on limited grounds }\end{array}$ \\
\hline 0 & 2 & 1 & 18 \\
\hline
\end{tabular}

The limiting grounds have three variations: for some persuasion is only allowed when facts / arguments are used and not imagery or emotions; for some persuasion is only allowed when it is used in the public debate or in a 'negotiation connection'; for some persuasion is only allowed when more sides are taken into consideration. However, some of the participants who strongly reject that public relations is also aimed at commercial publics and/or that public relations has to do with persuasion, do also see 'public' as 'public sphere'. This could, therefore, refer to another approach to public relations (Ruler \& Verčič, 2002, 2003).

The final question we proposed on the borders of public relations was the question of influence on organizational behavior. This item was mentioned in the first round by several participants as the most important task of public relations and was also part of the borderline discussion in the second round. For 15 participants it remained clear that public relations should have influence on organizational behavior. For all others public relations should co-operate with the personnel department in this matter. No one argued regarding the implementation of this co-operation; at least no one chose one of the given options or rejected any of them.

Yet, there was a strong undertone in the discussion, brought in by participants who did not want to reduce this field into a profession, but preferred to see it as a view on 
organization. It became very obvious in the discussion on ethics. For all participants this is an item that needs to be debated, especially while business ethics are becoming more and more important. It was felt that public relations ethics is intertwined with or perhaps even the same as business ethics. For some participants public relations goes beyond ethical behavior as such, but must be focused on societal dialogue. One participant stated: "Public Relations is also a question of continuously adjusting the decision processes within the organization into society's changing norms and values, and therefore, public relations is to discuss in public social norms and values relevant to the organization, in order to make the organization reflect these norms and values in its decision processes, and finally communicate to the public that the organization's behavior is legitimate".

It is obvious that public relations cannot be reduced to a professional function within or for an organization. It is - at least in Europe - also a certain approach or concept of organization. This implies that public relations works outside as well as inside the organization and that it could be a professional function as well as a part of functioning of other professionals as well.

\section{Public relations as a separate research field}

In the first two rounds, the participants unanimously stated that public relations must be a theory-based field in order to flourish. Many expressed the view that the field has a poor theoretical base. The data that we obtained from the research and education situation in various European nations showed that public relations in these countries is not commonly studied at a scientific level. We found very few well-developed research programs, other than one or two in Germany and England and to a lesser extent some in Austria, The Netherlands, Denmark and France. But also in these countries public relations is not highly stated within their universities. In addition, scientific journals seldom contain articles by European researchers. While this will partly be due to translation problems, we believe that part of the reason is also a lack of good research. And this will partly be caused by the fact that we differ in the answer of what is "good research". This has without doubt to do with the fact that the more important journals are all developed by US researchers and most of all aimed at empirical and, moreover, quantitative research. The fact that American researchers usually talk about qualitative research as "informal" research is informative in this respect.

However, it is obvious that in European countries neither practice nor science is very interested in theory development in public relations. The researchers do not form a critical mass yet. This has to do with cultural/theoretical differences but also with the approach to the theoretical field. As long as it is seen as an activity at the tactical level, it will never get attention. 


\section{The definition of the field}

In the first round we have asked the participants to give their definition in use. In the second round, we asked the participants to decide which key concepts - found in the given definitions in the first round - should definitely be part of a definition of public relations. In trying to find a common view, we continually returned to familiar AngloAmerican oriented concepts. This was not very helpful to find an answer to our research question. Therefore, it seemed more promising to try to overlook all the answers that were probably recited verbatim and that may have been very idealistic. Instead, we would concentrate on public relations as a phenomenon with certain distinct characteristics. In this way we could first try to find a description of this field's domain. Not until this had been done could we think about professionalization, nor could we talk about the skills, knowledge, tools or theories that needed to be developed. We forced ourselves not to spend too much time searching for common denominators, but rather to focus on different aspects, which we could connect to each other. Doing this exercise we hoped to find the 'true' dimensions of the domain and find out whether or not there is a distinct entity that we could call 'typical European public relations'.

The first two rounds generated a wide variety of views on public relations per se as well as on certain roles for public relations within (or on behalf of) an organization and in society at large. After studying the answers and searching for a description of the characteristics of the domain, we clustered all of the statements and ideas into four characteristics.

Figure 4. The four characteristics of European public relations

1. Reflective: to analyze changing standards and values and standpoints in society and discuss these with members of the organization, in order to adjust the standards and values / standpoints of the organization accordingly. This role is concerned with organizational standards, values and views and aimed at the development of mission and organizational strategies.

2. Managerial: to develop plans to communicate and maintain relationships with public groups, in order to gain public trust and / or mutual understanding. This role is concerned with commercial and other (internal and external) public groups and with public opinion as a whole and is aimed at the execution of the organizational mission and strategies.

3. Operational: to prepare means of communication for the organization (and its members) in order to help the organization formulate its communications. This role is concerned with services and is aimed at the execution of the communication plans developed by others.

4. Educational: to help all the members of the organization become communicatively competent, in order to respond to societal demands. This role is concerned with the mentality and behavior of the members of the organization and aimed at internal public groups. 
We examined these clusters in the third round discussion, in order to find out whether they can be used to define European public relations. Most participants were in favor of including these four characteristics within the scope of public relations. Furthermore, most of them regard these as definitive characteristics and perhaps even as interrelated dimensions of a European concept of public relations.

It is obvious that, within this public relations community, these characteristics were acceptable as a mean of defining the domain. According to statements from several European countries, like Denmark, Germany, The Netherlands, Sweden, it seems to be questionable whether public relations is seen as just maintaining relationships with certain public groups or is (also) to be seen as the public relationship any organization has with 'society' and the 'license to operate' any organization needs. This questioning stressed the attention for the reflective and educational characteristics even more, and almost all other participants accepted these additional characteristics to the wellknown managerial and operational ones.

\section{Discussion}

All disciplines and professions we know struggle with the multiplicity of often contradicting definitions. This multiplicity is sometimes explained away as a result of infancy and sometimes as a result of maturity of a field. In that respect, public relations is not different from any other academic social discipline or from any profession in practice. The different characteristics show that public relations is not just a professional function of managers and technicians. We, therefore, believe that we should view public relations as a multi-dimensional concept of a managerial, operational, coaching (educational) and reflective function in or for an organization. Moreover, it also shows that the mainstream approach of public relations as a professional management function needs to be expanded.

In The New Handbook of Organizational Communication Deetz (2001) approached the question "What is organizational communication" by explicating three different ways that are available for conceptualization. By transposing his presentation to the question "What is public relations?" we can do one of the following three things (Verčič et al., 2001).

First, we can focus on the development of public relations as a specialty in departments of public relations and public relations associations. As Deetz expects for his field of interest, we can also expect for public relations that adopting this approach would bring us to a classic complaint that there are as many public relations definitions as there are people practicing and teaching it: "It is not surprising that these reviews often contain laments about the disunity of the field. This may well be an artifact of the organizing principle used. "

A second approach to conceptualizing public relations focuses on a phenomenon that exists out there. This was the approach adopted by both Hutton in his article and by us in our EBOK Delphi research. But by confronting our results in the previous sec- 
tion, we have to admit that there is no unified phenomenon out there and that public relations "is not one phenomenon with many explanations; each form of explanation may conceptualize and explain different phenomenon. Fixed subdivisions are always a kind of theoretical hegemony" (Deetz, 2001). Public relations as a phenomenon may indeed differ between social spaces (e. g., continents) and looking for the lowest common denominator is worthless.

A third way Deetz proposes is to approach the issue of public relations as a way to describe and explain an organization. That is exactly what other managerial disciplines and professions are doing: finances describe and explain organizations from a financial perspective, lawyers from a legal perspective, marketing from a market perspective. What we need to find for public relations is "a distinct mode of explanation or way of thinking about organizations. "What we need to develop is a public relations theory of organizing and organization.

What is the specific characteristic of public relations approach to organizing and organization? Relationships are not, since they are claimed by general management, marketing, social and organizational psychology and many other disciplines. What distinguishes the public relations manager when he sits down at the table with other managers is that he brings to the table a special concern for broader societal issues and approaches to any problem with a concern for implications of organizational behavior towards and in the public sphere. It is precisely this concern that is implicit in definitions of public relations as "relationships management" and as "communication management", in both "image management" and "reputation management", and is fundamental for understanding of some of the fundamental concepts like "stakeholders", "public(s)" and "activists". In Europe this is specially contained in the reflective and educational characteristics of public relations (the second one pertaining to the development of social and communicative competence of and in an organization and not to a dissemination of information in order to educate publics), but in the U. S. it has special features in situations concerned with "non-discrimination"," "non-harassment" and different kind of "non-isms" (like "non-ageism"), which all seem very different to how the underlying similar problems are dealt with in Europe.

A bridge that may bring us from different approaches to public relations together is our common approach to organizing and organization. In that respect Olasky's alternative exposition of the U. S. public relations history may be a very valuable starting point - by differentiating "public" from "private" relations. Public relations practitioners and academics approach to organizing and organizations from a "public" perspective, being concerned with phenomena of reflectivity (of organizational behavior) and legitimacy.

Seen from this standpoint public relations is not just a phenomenon to be described and defined. It is first of all a strategic process of viewing an organization from an "outside", and more precise, a public view. Its primary concerns are organization's inclusiveness and its preservation of the "license to operate". As marketing is viewing organization from a market view, public relations is viewing organization from a 
public view (meant as "public sphere"). We, therefore, like to broaden the relational and communicative approaches to public relations with or into a public or reflective approach of which the relational and communicative approaches of public relations can be seen as parts.

This is what we know now. A third phase of our research project into public relations and communication management in Europe will be an empirical cross-national research project on public relations and public trust in order to find out what is going on in different European countries in the field of public relations.

\section{Appendix: list of participating countries}

Austria, Belgium, Bulgaria, Croatia, Denmark, Finland, France, Germany, Hungary, Ireland, Italy, Latvia, Netherlands, Norway, Poland, Portugal, Russia, Slovakia, Slovenia, Spain, Sweden, Switzerland, Ukraine, United Kingdom, Yugoslavia. After we completed the Delphi, Greece, Malta and Turkey also joined the EBOK project and contributed to the Europe book.

\section{References}

Bernays, E. L. (1986) The Late Years: Public Relations Insight 1956-1986, Rhineback, NY: H\&M Publishers.

Cheney, G., and Dionispoulos, G. N. (1987) "Public Relations? No, Relations with Publics: A RhetoricalOrganizational Approach to Contemporary Corporate Communications,", in Carl Botan and Vincent Hazleton, Jr. (eds.), Public Relations Theory, Hillsdale, NJ: Lawrence Erlbaum, pp. 135-157.

Cole, R. S. (1981) The Practical Handbook of Public Relations, Englewood Cliffs, NJ: Prentice-Hall.

Deetz, S. (2001) "Conceptual foundations", in F. M. Jablin \& L. L. Putnam (Eds.). The New Handbook of Organizational Communication: Advances in Theory, Research, and Methods, Thousand Oaks: Sage, pp. 3-46.

Grunig, J. E. (Ed.) (1992) Excellence in Public Relations and Communication Management, Mahwah: Erlbaum.

Grunig, J. E. (1997) "A Situational Theory of Publics: Conceptual History, Recent Challenges and New Research”, in Danny Moss, Toby MacManus and Dejan Ver i (Eds.). Public Relations Research: An International Perspective, London: International Thomson Business Press, pp. 3-48

Habermas, J. (1962) Strukturwandel der Oeffentlichkeit, Darmstadt: Hermann Luchterhand Verlag

Heath, R. L. (Ed.) (2000). Handbook of Public Relations, Thousand Oaks: Sage.

Hutton, J. G. (1999). “The Definition, Dimensions, and Domain of Public Relations”, Public Relations Review, 26 (2): 199-214.

Jensen, I. (2000). "Public Relations and the Public Sphere in the Future", Paper presented at the $7^{\text {th }}$ International Public Relations Symposium, Bled, Slovenia, 7-9 July

Ledingham, J. A. \& Bruning, S. D. (Eds.) (2000). Public Relations as Relationship Management, Mahwah NJ: Erlbaum.

Nessman, K. (2000). “The origins and developments of public relations in Germany and Austria”, in: Danny Moss, Dejan Verčič and Gary Warnaby (Eds.). Perspectives on Public Relations Research, London and New York: Routledge, pp. 212-225.

Oeckl, A. (1976). Handbuch der Public Relations: Theorie und Praxis der Oeffentlichkeitsarbeit in Deutschland und der Welt, München: Süddeutscher Verlag. 
Olasky, M. N. (1989). Corporate Public Relations. A New Historical Perspective, Hillsdale NJ: Erlbaum. Price, V. (1992). Public opinion, Newbury Park: Sage.

Ronneberger, F. \& Rühl, M. (1992). Theorie der Public Relations, ein Entwurf, Opladen: Westdeutscher Verlag.

Ruler, B. van, \& Verčič, D. (2002) '21 '1st Century Communication Management - the People, the Organization. In: P. Simcic Bronn \& R. Wiig (eds.). Corporate Communication. A Strategic Approach to Building Reputation, pp. 277-294. Oslo: Gyldendal Akade, pp. 274-294

Ruler, B. van,\& Verčič, D. (Eds.) (2003a). Public Relations and Communication Management in Europe. A Nation-by-Nation Introduction to Theory and Practice. Berlin/New York: Mouton DeGruyter.

Ruler, B. van, \& Verčič, D. (2003b). Reflective Communication Management: A Public View on Public Relations, paper presented at the $53^{\text {rd }}$ Conference of the International Communication Association, San Diego, USA, May, 23-27

Ruler, B. van, Verčič, D., Buetschi, G., \& Flodin, B. (2001). Public Relations in Europe: A kaleidoscopic picture. Journal of Communication Management, Vol. 6, 2, pp. 166-175.

Verčič, D. (2000). The European Body of Knowledge, Journal of Communication Management, Vol. 4, 4, pp. 341-354.

Verčič, D., Ruler, B. van, Buetschi, G., \& Flodin, B. (2001). On the definition of public relations: A European view (27) Public Relations Review, nr. 4, pp. 373-387

Verčič, D., \& Sriramesh, K. (Eds.). 2003). The Global Public Relations Handbook. Mahwah NJ: Erlbaum. White, J. (1991). How to Understand and Manage Public Relations: A Jargon-Free Guide to Public Relations Management. London: Random. 